\begin{tabular}{|l|c|c|c|c|c|} 
J. Tek. Ling & Vol.11 & No.3 & Hal. 459 - 474 & Jakarta, September 2010 & ISSN 1441-318X \\
\hline
\end{tabular}

\title{
PEMANFAATAN POTENSI GAS METANA DI PABRIK KELAPA SAWIT SEI SILAU, PTPN3, SUMATERA UTARA
}

\author{
Irhan Febijanto*) \\ *) Pusat Teknologi Pengembangan Sumberdaya Energi, Deputi Teknologi Informatika, \\ Energi dan Mineral- BPPT
}

\begin{abstract}
Water waste in Palm Oil Mill (POM) is not effectively utilized yet. Before waste water discharge from POM, the waste water is processed by an aerobic treatment in several ponds to decrease the influence of organic matter. Methane gas generated in the anaerobic ponds is a Green Gas House giving a contribution to global warming impact. In Palm Oil Mill of Sei Silau located in North Sumatera, the potential generated methane gas in two anaerobic ponds has been investigated using measurement of Chemical Oxygen Demand (COD) of waste water in the sites. Based on the potential generated methane gas, the reduction of GHG emission is calculated, and the feasibility of the project as CDM project was evaluated.
\end{abstract}

Keywords : Pabrik Kelapa Sawit, gas metana, gas rumah kaca, proyek CDM (Clean Development Mechanism),, COD (Chemical Oxygen Demand)

\section{PENDAHULUAN}

Industri kelapa sawit di Indonesia merupakan yang terbesar di dunia. Limbah dari proses pengolahan buah kelapa sawit menjadi minyak kelapa sawit menghasilkan dua macam limbah, limbah padat dan limbah cair. Limbah padat berupa cangkang dan serabut kelapa sawit telah dimanfaatkan sebagai bahan bakar di pabrik kelapa sawit semenjak pabrik didirikan untuk menghasilkan listrik dan uap air yang digunakan untuk proses di pabrik. Limbah cair sampai saat ini tidak dimanfaatkan untuk kebutuhan lain selain untuk land aplication di perkebunan.

Air limbah hasil pengolahan di Pabrik Kelapa Sawit (PKS) pada umumnya diolah melalui cara pond treatment, yang menyediakan beberapa pond, dimana limbah mengalami degradasi dalam kurun waktu tertentu di tiap-tiap pond. Umumnya pond terdiri dari cooling pond, anaerobik pond, aerobik pond dan facultative pond.

Pada kolam anaerobik, degradasi komponen organik pada air limbah diikuti dengan produksi gas metana. Timbulnya gas metana ini terjadi karena kondisi lingkungan pada kolam mendukung bakteri penghasil gas metana bekerja secara optimum.

Pada studi ini, dilakukan kajian pemanfaatan gas metana yang timbul dari kolam anaerobik di PKS milik PT Perkebunan Nusantara (PTPN) 3. Studi ini dilaksanakan untuk menjawab krisis energi dengan memanfaatkan limbah dan penanggulangan efek pemanasan global yang disebabkan oleh Gas Rumah Kaca (GRK) seperti gas metana. 


\subsection{PT Perkebunan Nusantara 3}

PT Perkebunan Nusantara 3 merupakan salah satu dari 14 Badan Usaha Milik Negara (BUMN) Perkebunan yang bergerak dalam bidang usaha perkebunan, pengolahan dan pemasaran hasil perkebunan. Kegiatan usaha Perseroan mencakup usaha budidaya dan pengolahan tanaman kelapa sawit dan karet. Produk utama Perseroan adalah Minyak Sawit (CPO) dan Inti Sawit (Kernel) dan produk hilir karet

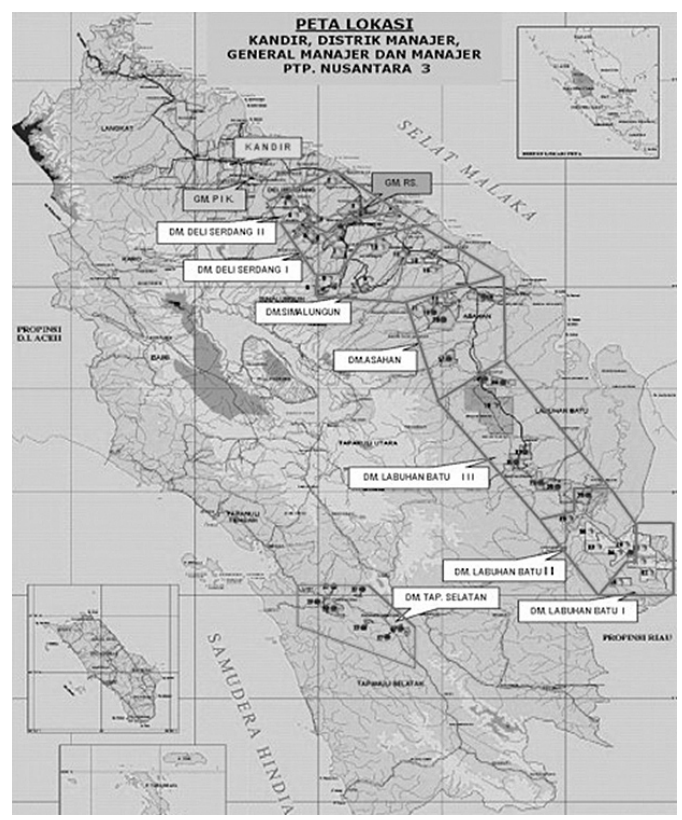

Gambar 1 Lokasi PKS

PTPN 3 berasal dari perkebunan milik Belanda yang pada 1958 diambil alih oleh Pemerintah Republik Indonesia. Pada tahun 1974 bentuk perusahaan berubah status menjadi PT Perkebunan (Persero). Pada tahun 1994, untuk meningkatkan efisiensi dan efektifitas dilakukan penggabungan antara 3 (tiga) BUMN Perkebunan yang terdiri dari PT Perkebunan III (Persero), PT Perkebunan IV (Persero), PT Perkebunan $\mathrm{V}$ (Persero) disatukan pengelolaannya ke dalam manajemen PT Perkebunan Nusantara III (Persero). Selanjutnya pada tahun 1996 ketiga perseroan tersebut digabung dan diberi nama PT Perkebunan Nusantara III (Persero) dengan kantor pusat di Medan, Sumatera Utara.

PTPN 3 ini memiliki 10 pabrik kelapa sawit (PKS) yang berlokasi memanjang ke arah selatan dari Medan ke arah propinsi Riau, seperti ditunjukkan di gambar 1 . Nama ke 10 PKS tersebut ditunjukkan di tabel di bawah, dimana dari 10 tersebut 6 PKS berkapasitas 60 ton/jam, sisanya berkapasitas 30 ton/jam.

Tabel 1 Pabrik Kelapa Sawit PTPN 3

\begin{tabular}{|c|c|c|c|}
\hline No & Nama PKS & Lokasi & $t /$ jam \\
\hline 1 & Rambutan & $\begin{array}{l}\text { Sei Rampah, Deli } \\
\text { Serdang }\end{array}$ & 30 \\
\hline 2 & Aek Torop & $\begin{array}{l}\text { Kota Pinang, } \\
\text { Labuhan Batu }\end{array}$ & 60 \\
\hline 3 & $\begin{array}{l}\text { Aek } \\
\text { Nabara }\end{array}$ & $\begin{array}{l}\text { Bilah Hilir, Labuhan } \\
\text { Batu }\end{array}$ & 60 \\
\hline 4 & Sisumut & $\begin{array}{l}\text { Kota Pinang, } \\
\text { Labuhan Batu }\end{array}$ & 30 \\
\hline 5 & Aek Raso & $\begin{array}{l}\text { Kota Pinang, } \\
\text { Labuhan Batu }\end{array}$ & 30 \\
\hline 6 & Sei Daun & $\begin{array}{l}\text { Kota Pinang, } \\
\text { Labuhan Batu }\end{array}$ & 60 \\
\hline 7 & Torganda & $\begin{array}{l}\text { Kota Pinang, } \\
\text { Labuhan Batu }\end{array}$ & 60 \\
\hline 8 & Sei Silau & Buntu Pane, Asahan & 60 \\
\hline 9 & Sei Meranti & Labuhan Batu & 60 \\
\hline 10 & Sei Bruhur & Labuhan Batu & 30 \\
\hline
\end{tabular}

\subsection{Waktu dan Lokasi Penelitian}

Gambar 1 menunjukkan lokasi keseluruhan pabrik kelapa sawit dan perkebunan milik PTPN 3. Area lokasi terletak bagian Timur propinsi Sumatera Utara, memanjang dari bagian utara kota Medan, memanjang ke arah Selatan sampai perbatasan propinsi Sumatera Utara dan Riau. (kota Medan) sebelah timur propinsi Sumatera Utara ke arah selatan sampai propinsi Riau.

Dari 10 PKS milik PTPN 3, dalam studi ini dipilih PKS berkapasitas 60 t/jam dengan operasional konstan. Diantara PKS tersebut 
PKS Sei Silau memiliki jumlah pengolahan TBS terbesar diantara PKS lain berkapasitas $60 \mathrm{t} / \mathrm{jam}$.

\subsection{Kondisi Kolam Limbah di PKS pada umumnya}

Gambar 2 menunjukkan kondisi umum kolam limbah di PKS Sei Silau. Nampak di gambar sebelah kanan adalah kondisi kolam pada pagi hari, dimana minyak kotor (miko) pada kolam anaerobik menggumpal, di sebelah kanan adalah kondisi limbah pada siang hari.

Kolam limbah ini mempunyai luas rata rata $50 \mathrm{~m}^{2}$ lebih dan kedalaman lebih dari $2 \mathrm{~m}$. Pendangkalan kolam terjadi dengan cepat, karena padatan dialirkan ke kolam bersamaan dengan air limbah. Pembersihan lumpur/sekam tidak secara periodik dilakukan oleh PKS, hal ini mempercepat pendangkalan kolam. Pada saat dilakukan pembersihan karena kendala biaya, biasanya sekam hanya ditumpuk begitu saja di pinggir kolam.

Secara kasat mata, dari permukaan kolam pengolahan limbah nampakgelembunggelembung yang timbul diakibatkan adanya gas metana. Gas metana ini bisa terbakar jika terkumpul dalam jumlah yang banyak di atas permukaan.

Pada PKS Sei Silau, air limbah dipakai untuk pupuk di kebun dengan mengalirkan melalui pipa air limbah ke kebun sejauh 3 $\mathrm{km}$. Konsentrasi BOD dijaga agar tidak lebih rendah dari $5000 \mathrm{mg} / \mathrm{l}$. Sebagian air dari kolam terakhir dikembalikan lagi ke kolam anaerobik 1 dan 2 secara bersamaan melalui pipa pararel. Air disirkulasikan dengan 2 unit pompa berkapasitas $30 \mathrm{~m}^{3} / \mathrm{jam}$.

\subsection{Limbah Cair}

Limbah cair dari pabrik kelapa sawit disebut juga POME, Palm Oil Mill Effluent. Limbah air ini berasal dari air kondensasi proses sterilisasi sekitar $15-20 \%$, air proses klarifikasi \& sentrifugasi sekitar
$40-50 \%$, dan air dari claybat/hydroclone sekitar $9-11 \%{ }^{11}$.

Limbah cair yang dihasilkan dari pabrik pengolahan minyak kelapa sawit (PKS) dapat memberikan dampak negatif bagi lingkungan karena memiliki kandungan $B O D$ (Biochemical Oxygen Demand) dan COD (Chemical Oxygen Demand) yang sangat tinggi. Tanpa proses degradasi limbah cair ini berpotensi mencemari lingkungan dan menimbulkan bau. Untuk itu sebelum dialirkan ke lingkungan sekitar, kadar BOD dan COD limbah cair tersebut harus diturunkan sesuai dengan baku mutu.

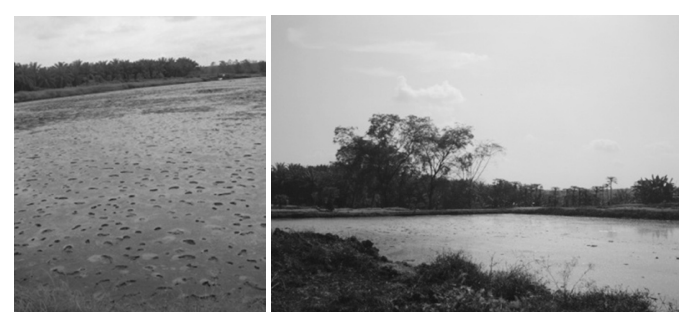

Gambar 2 Minyak yang mengental (seb. kiri) dan kondisi kolam limbah pada umumnya (seb kanan)

Air limbah digunakan untuk Land Aplication maka sesuai dengan aturan KEPMENLH/28/20032), tidak lebih dari $5.000 \mathrm{mg} / \mathrm{ltr}$. Dengan nilai BOD ini, limbah cair dianggap masih mempunyai nutrisi yang cukup sebagai pupuk cair. Air limbah yang dibuang ke sungai, sesuai KEPMENLH/28/2003, nilai BOD harus dibawah $150 \mathrm{mg} / \mathrm{ltr}^{2}$.

Penurunan suhu air limbah dilakukan dengan menggunakan cooling pond/cooling tower, setelah itu air limbah dialirkan ke kolam anaerobik.

Sirkulasi air dari kolam aerobik ke kolam anaerobik dilakukan dengan tujuan menurunkan suhu kolam, agar sesuai untuk suhu lingkungan bakteri pembusuk, dan untuk menambah kuantitas bakteri dari kolam anaerobik. Umumnya untuk sirkulasi air limbah digunakan 2 unit pompa dengan kapasitas 30-40 $\mathrm{m}^{3} / \mathrm{jam}$. 
Pada PKS Sei Silau, air limbah setelah melalui outlet PKS, dialirkan ke deoiling tank, lalu ke cooling pond. Pada cooling pond ini, dilakukan pengambilan minyak dengan drum penjilat. Minyak yang diambil dikembalikan lagi ke pabrik untuk diolah menjadi CPO (Crude Palm Oil). Setelah itu air limbah dialirkan ke kedua kolam anaerobik secara pararel, dan setelah melalui kolam aerobik, air limbah digunakan untuk Land Aplication, dengan mengalirkan dengan pipa sejauh 3 km ke perkebunan. Sirkulasi air dari kolam aerobik ke anaerobik menggunakan 2 unit pompa dengan kapasitas $30 \mathrm{~m}^{3} / \mathrm{jam}$. Luasan area kolam adalah panjang : $67,5 \mathrm{~m}$, lebar : 40,0m dan kedalaman: 5,0 m.

\subsection{Proses Pembentukan Biogas}

Biogas adalah campuran gas yang dihasilkan dari proses degradasi zat-zat organik yang terkandung di dalam air limbah hasil proses ektraksi tandan kosong menjadi minyak kelapa sawit.

Proses degradasi yang terjadi dalam kondisi anaerobik ini, dapat dibagi menjadi beberapa fase, yaitu hidrolisis, asetogenesis, dan metanogenesis. Pada tahap hidrolisis terjadi dekomposisi bahan biomassa kompleks menjadi glukosa sederhana memakai enzim yang dihasilkan oleh mikroorganisme sebagai katalis. Hasil penting tahap pertama ini adalah bahwa biomassa menjadi dapat larut ke dalam air dan mempunyai bentuk kimia lebih sederhan yang lebih sesuai untuk tahap berikutnya. Di langkah kedua terjadi dehidrogenasi (pengambilan atom hidrogen dari bahan biomassa) yaitu perubahan glukosa jadi asam asetat, karboksilasi (pengambilan grup karboksil) asam amino, memecah asam lemak ranti panjang jadi asam ranti pendek dan menghasilkan asam asetat sebagai produk akhir. Tahap ketiga adalah pembentukan biogas dari asam asetat lewat fermentasi oleh bakter metanogenik. Salah satu bakteri metanogenik yang banyak didapat di lumpur adalah methanobachillus omelianskii. Metabolisme anaerobik selulosa melibatkan reaksi komplek dan prosesnya lebih sulit daripada reaksi anaerobik bahanbahan organik lain seperti karbohidrat, protein dan lemak ${ }^{3)}$.

Fase yang penting dalam pembentukan gas metana adalah fase metanogenesis, pada fase ini bakteria acetoclastic methanogenic mengkonversi senyawa alkohol, asetat, hidrogen $\left(\mathrm{H}_{2}\right)$ dan karbodioksida $\left(\mathrm{CO}_{2}\right)$ menjadi mentana $\left(\mathrm{CH}_{4}\right)^{4)}$.

Pada umumnya biogas terdiri atas gas metana $\left(\mathrm{CH}_{4}\right) 50 \%$ sampai $70 \%$, gas karbon dioksida $\left(\mathrm{CO}_{2}\right) 30 \%$ sampai $40 \%$. Hidrogen $\left(\mathrm{H}_{2}\right) 5 \%$ sampai $10 \%$ dan gas-gas lainnya dalam jumlah yang sedikit 5,6 ).

Biogas memiliki berat kurang lebih 20\% lebih ringan dibandingkan udara dan bersuhu pembakaran antara 650 sampai $750^{\circ} \mathrm{C}$. Biogas tidak berbatu dan berwarna, dan apabila dibakar akan menghasilkan nyala api biru cerah seperti gas LPG. Nilai kalor gas metana adalah $20 \mathrm{MJ} / \mathrm{m}^{3}$ dengan efisiensi pembakaran $60 \%$ pada konvensional kompor biogas ${ }^{5}$.

\subsection{Bakteri Metanogenik}

Bakteri Metanogenik atau metanogen adalah bakteri yang terdapat pada bahan bahan organik dan menghasilkan metan dan gas gas lainnya dalam proses keseluruhan hidupnya pada keadaan anaerobik. Organisme hidup ini mempunyai kecenderungan untuk menyukai kondisi tertentu dan peka pada iklim mikro dalam pencerna. Terdapat banyak spesises dari hemanogen dan variasi sifat-sifatnya. Variasi sifat-sifat biokimia ini menyebabkan produksi biogas juga bervariasi ${ }^{7}$.

Bakteri metanogenik dibandingkan dengan bakteri-bakteri pembentuk asam lainnya berkembang lambat dan sensitif terhadap perubahan mendadak pada kondisi kondisi fisik dan kimiawi. Sebagai contoh, penurunan $2^{\circ} \mathrm{C}$ secara mendadak pada slurry mungkin secara signifikan berpengaruh pada pertumbuhannya dan laju produksi gas ${ }^{8)}$. 
Pembentukan gas ini dapat terjadi diantara suhu $4-60^{\circ} \mathrm{C}$, dan dalam suhu konstan. Pada suhu optimum bakteri akan menghasilkan enzim lebih banyak.

Bakteri penghasil metana/bakteri metanogenik ini juga sensitih terhadap perubahan $\mathrm{pH}$. Perubahan Aktivitas metanogenik ini berubah menjadi aktif pada $\mathrm{pH}$ antara $7-8^{9}$, sedangkan $\mathrm{pH}$ optimum untuk jenis bakteri ini adalah 6,4-7,4 ${ }^{10)}$.

Proses anaerobik pada pengolahan air limbah kelapa sawit untuk menghasilkan gas metana, terdiri daru dua tahap, yaitu tahap pembentukan asam dan tahal pembentukan metana. Dimana pengaturan $\mathrm{pH}$ sangat penting pada proses awal. pH pada kondisi awal 7, akan memberikan peningkatan laju produksi biogas lebih baik dibandingkan dengan konsis $\mathrm{pH}$ yang lain ${ }^{11}$.

\subsection{Pengambilan Sample Air Limbah dan Analisa COD}

Pengambilan sample air limbah untuk analisa COD (Chemical Oxygen Demand) dilakukan di inlet dan outlet kolam anaerobik. Analisa COD dilakukan untuk memprediksi jumlah gas metana yang dihasilkan dari hasil pemrosesan dekomposisi zat organik pada kolam anaerobik.

Korelasi linier dari penurunan COD dengan peningkatan gas metana yang dihasilkan di kolam anaerobik telah ditunjukkan dengan jelas oleh penelitian sebelumnya ${ }^{(12)}$.

Metoda standar penentuan kebutuhan oksigen kimiawi atau Chemical Oxygen Demand (COD) yang digunakan saat ini adalah metoda yang menggunakan oksidator luas, Kaliom bikormat, $\mathrm{CaCr}_{2}$, asam sufat pekat dan perak sulfa sebagai katalis.

Sedangkan metodologi pegukurannya terdiri dari seperti di bawah ini ${ }^{13)}$, yaitu :

a. SNI 6989.2:2009 - refluks tertutup secara spektrofotometri

b. SNI 6989.73:2009 - refluks tertutup secara titimetri c. SNI 06-6989.15-2004 - refluks terbuka secara titrimetri

d. SNI 06-6989.2-2004- refluks terbuka secara spektrofotometri

Pengukuran COD dari kolam limbah PKS Sei Silau dilaksanakan di laboratorium Suconfindo yang menggunakan cara SNI 06-6989.2-2004 - refluks terbuka secara spektrofotometri

\subsection{Pemanfaatan Sebagai Sumberdaya Energi}

Pemanfaatan gas metana sebagai energi pada dasarnya belum banyak diimplementasikan. Selain kendala investasi juga kendala teknologi menjadi kendala yang umum.

Gas metana yang berasal dari kolam dapat diinjeksikan kedalam biogas engine atau ke dalam boiler sebagai bahan bakar pengganti dari fiber maupun cangkang. Pemanfaatan gas metana dari kolam limbah di PKS belum banyak dilakukan di Indonesia, tetapi sudah banyak diimplementasikan di Malaysia, sebagai proyek CDM ${ }^{14}$.

\subsection{Pengurangan Emisi Gas Rumah Kaca}

Pemanfaatan gas metana di kolam limbah baik itu sebagai energi atau pun dibakar saja, dapat dimasukkan sebagai usaha untuk mengurangi efek GRK.

Pengurangan emisi terjadi ketika gas metana dibakar, dan diubah menjadi karbondioksida, $\mathrm{CO}_{2}$. Gas $\mathrm{CO}_{2}$ termasuk GRK, akan tetapi mempunyai daya rusak 1/21 lebih kecil dari $\mathrm{CH}_{4}$. Sehingga konversi $\mathrm{CH}_{4}$ ke $\mathrm{CO}_{2}$ merupakan pengurangan dampak emisi.

Teknologi penangkapan gas metana dari kolam limbah PKS, untuk dimanfaatkan sebagai energi maupun dibakar saja, secara teoritis bukan merupakan hal baru. Hanya karena membutuhkan biaya yang besar, teknologi tersebut tidak banyak 
diimplementasikan, karena membutuhkan biaya yang besar, dan dapat menjadi beban bagi perusahaan.

Dengan adanya mekanisme CDM yang memberikan insentif terhadap proyekproyek yang mengurangi emisi Gas Rumah Kaca (GRK), aplikasi teknologi ini mulai dikembangkan.

\subsection{Mekanisme Clean Development Mechanism (CDM)}

Mekanisme Clean Development Mechanism (CDM) adalah suatu mekanisme yang merupakan komitmen dunia international untuk mengurangi Green House Gas (GHG), seperti gas $\mathrm{CO}_{2}, \mathrm{~N}_{2} \mathrm{O}, \mathrm{CH}_{4}$, dsb. GHG ini merupakan penyebab dari pemanasan global.

Melalui mekanisme CDM, negara maju (yang tergabung dalam ANNEX I) bersama negara-negara berkembang untuk bekerja sama mengurangi emisi gas rumah kaca.

Keuntungan program CDM bagi negara berkembang antara lain adalah :

a. Adanya aliran investasi asing, yang dapat membantu kelancaran finansial proyek.

b. Keikutsertaan investor asing dalam proyek dapat memperkecil resiko bagi pengembang lokal.

c. Adanya kemungkinan transfer teknologi, yang dapat membantu perkembangan teknologi lokal.

d. Jika pendanaan melalui pinjaman bank asing, biasanya akan mendapatkan bunga yang rendah dari biasa.

Dari keuntungan-keuntungan yang ada, keuntungan mendapatkan finansial atau adanya investasi asing merupakan hal yang menarik dari program CDM bagi pengembang lokal.

Bagi negara maju, program CDM merupakan cara pengurangan emisi gas rumah kaca yang dapat dilakukan dengan biaya murah dibandingkan dengan pelaksanaan di negaranya sendiri.

Program CDM sendiri mempunyai prosedur yang sudah ditentukan oleh UNFCCC (United Frameworks for Convention Climate Change). Prosedur tersebut harus dilakukan agar suatu proyek dapat diakui secara resmi oleh UNFCCC, selaku badan yang memberikan sertifikat terhadap sebuah proyek CDM. Prosedur tersebut ditunjukkan dalam gambar 4 .

Tiap langkah yang dilakukan dalam proses administrasi CDM, dapat memakan waktu lebih dari satu tahun. Intinya perlu dilakukan klarifikasi terhadap pelaksanaan proyek CDM apakah pengurangan $\mathrm{CO}_{2}$ terjadi dengan pasti, dan klarifikasi methodologi perhitungan bisa dipertanggungjawabkan.

Pemanfaatan mekanisme CDM, dapat mengurangi resiko ketidaklayakan secara ekonomis suatu proyek yang memakai energi terbarukan. Pemasukan dari penjualan kredit karbon dapat menjadi pemasukan tambahan selain pemasukan dari penjualan listrik. Rata rata hasil dari penjualan kredit karbon ini dapat menambah nilai IRR sebanyak 1-2\% dan dapat meningkatkan gross keuntungan sebesar $10-20 \%$

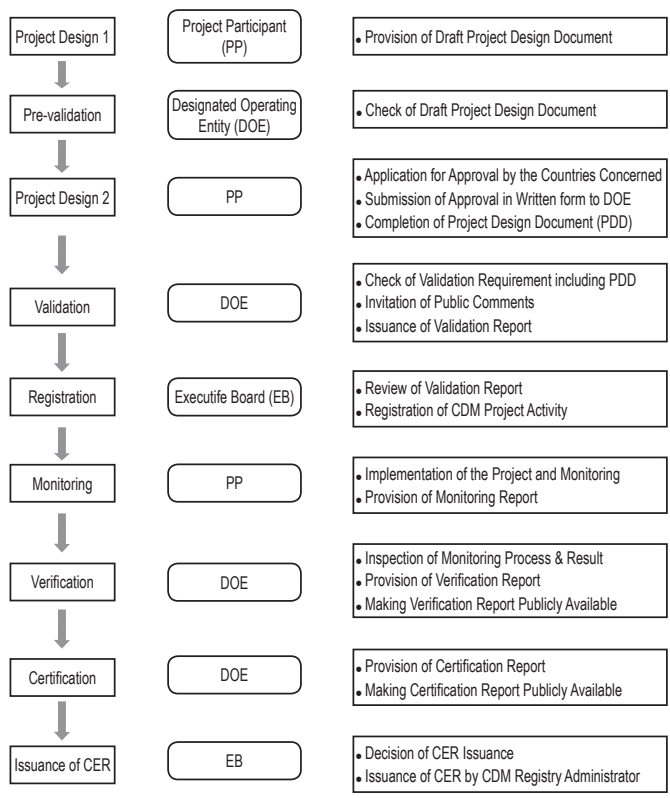

Gambar 3 Proses adminstrasi CDM 


\section{METODOLOGI}

\subsection{Pemilihan Lokasi}

Kapasitas produksi PKS Sei Silau relatif tinggi dan stabil dibandingkan PKS lain milik PTPN3, sehingga menjadi pilihan obyek studi. PKS ini terletak di Kabupaten Asahan, Sumatera Utara, berlokasi di koordinat, $2^{\circ}$ 54' 7,50" Lintang Selatan dan 99 30' 30,30" Bujur Timur.

\subsection{Rasio Air Limbah}

Rasio air limbah untuk tiap ton Tandan Buah Segar (TBS) yang diproses berkisar antara $0,55-0,65 \mathrm{~m}^{3} / \operatorname{ton}^{(15)}$. Dari perbandingan PKS di Malaysia (5 PKS), di Indonesia (3 PKS) dan di Thailand (1 PKS), didapatkan rata-rata perbandingan antara volume limbah cair terhadap 1 ton TBS, yaitu $54,8 \%{ }^{16)}$.

Berdasarkan pertimbangan konservatif, perbandingan air limbah per satu ton TBS pada studi ini diambil $54,8 \%$.

\subsection{Pengukuran Kualitas Air}

Pengukuran kualitas air digunakan parameter COD. Dari selisih nilai COD air limbah yang sudah diproses dan telah diproses dapat dihitung jumlah gas metana yang dihasilkan dari air limbah. Pengukuran COD ini diakukan di laboratorium Sucofindo, Medan. Pengambilan sample air untuk pengukuran COD dilakukan 10 hari berturutturut.

Sample diambil di tiap inlet dan outlet kolam anaerobik. Sample dimasukkan ke dalam botol plastik (gambar 4) kemudian dimasukkan ke dalam cooler box untuk dibawa ke laboratorium.

Gambar 5 menunjukkan sistem aliran air di PKS Sei Silau, dimana dari cooling pond air dialirkan secara pararel, dan dari kolam akhir air disirkulasikan ke kolam anaerobik 1 dan 2. Pengambilan COD dilaksanakan di inlet dan outlet masing-masing kolam anaerobik 1 dan 2.

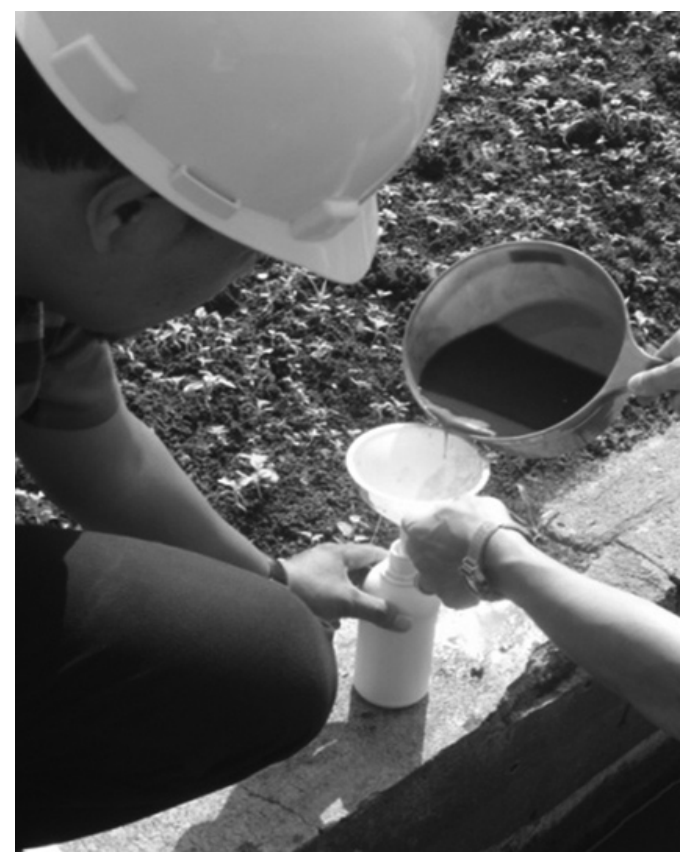

Gambar 4 Pengambilan Sample Air Limbah untuk Pengukuran COD.

\subsection{Potensi Produksi Gas Metana}

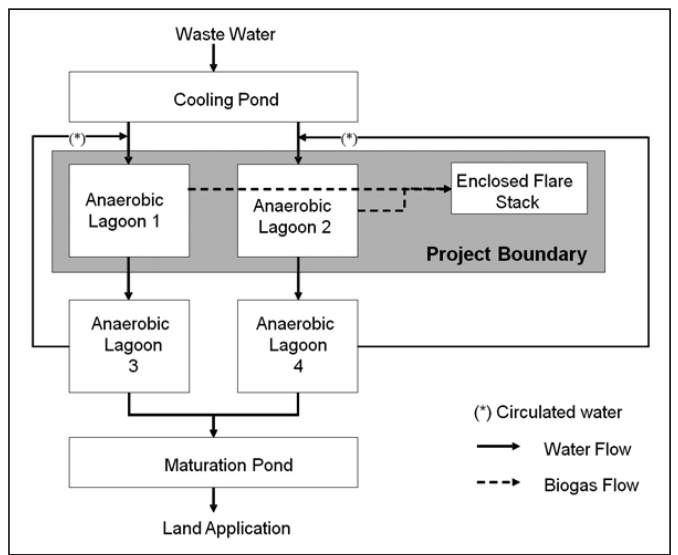

Gambar 5 Lay out kolam limbah PKS Sei Silau

Potensi produksi gas metana atau Baseline emission dari proyek penangkapan gas metana pada sistem pengolahan limbah air dapat ditunjukkan dengan persamaan 
pada AMS-III.H (Approved Methodology) (version 13):"Methane recovery in waste treatment"17):

\section{1) Perhitungan Gas Metana}

Perhitungan potensi gas metana ditentukan melalui metodologi UNFCCC. Nilai parameter untuk COD, didapat dari hasil rata-rata nilai COD dari pengukuran selama 10 hari berturut turut.

$\mathrm{BE}_{\mathrm{y}}\left(\mathrm{t}-\mathrm{CO}_{2^{-} \mathrm{e} / \mathrm{yr}}\right)=\left\{\mathrm{BE}_{\text {power,y }}+\mathrm{BE}_{\mathrm{ww}, \text { treatment,y }}+\right.$
$\left.\mathrm{BE}_{\mathrm{s}, \text { treatment,y }}+\mathrm{BE}_{\mathrm{ww} \text {,discharge }, \mathrm{y}}+\mathrm{BE}_{\mathrm{s}, \text { final }, \mathrm{y}}\right\} \ldots \ldots \ldots \ldots$ (1)

dimana,

BE

: emisi baseline pada tahun y $\left(\mathrm{t}-\mathrm{CO}_{2}\right)$

BE $_{\text {power,y }} \quad$ : emisi baseline dari listrik atau kebutuhan bahan bakar pada tahun y $\left(\mathrm{t}-\mathrm{CO}_{2}\right)$

$\mathbf{B E}_{\text {ww,treatment,y }}$ : emisi baseline dari pengolahan limbah cair $\left(\mathrm{t}-\mathrm{CO}_{2}\right)$

$\mathbf{B E}_{\mathrm{s} \text {,treatment,y }} \quad$ : emisi baseline dari pengolahan sludge/lumpur $\left(\mathrm{t}-\mathrm{CO}_{2}\right)$

$\mathbf{B E}_{\text {ww,discharge,y }}$ : emisi baseline dari pembusukan karbon organik dari hasil pengolahan limbah cair yang dibuang ke sungai/ laut(t-CO $\mathrm{CO}_{2}$

$\mathbf{B E}_{\mathrm{s,final,y}} \quad$ : emisi baseline dari pembusukan an organik lumpur $\left(\mathrm{t}-\mathrm{CO}_{2}\right)$

Pada proyek ini, listrik yang dipakai untuk menjalankan proses pengolahan limbah cair menggunakan bahan bakar biomasa (serabut dan cangkang) yang diambil dari limbah pembuatan CPO di pabrik, sehingga energi listrik yang dihasilkan tidak menghasilkan emisi, maka $\mathrm{BE}_{\text {power,y }}=0$.

Pengolahan sludge/lumpur pada proyek ini tidak mengalami perubahan dengan adanya proyek ini, dimana lumpur diambil dari kolam an aerobik secara berkala untuk menjaga kualitas air yang dikeluarkan ke areal perkebunan, sehingga dalam proyek ini $\mathrm{BE}_{\mathrm{s}, \text { reatment, } \mathrm{y}}=0$.

Dalam proyek ini, limbah air yang keluar dari kolam an aerobic diolah dengan baik di kolam aerobic, maka $\mathrm{BE}_{w_{w} \text {,discharge, } y}=0$. Dan karena lumpur digunakan sebagai pupuk/soil application maka $\mathrm{BE}_{\mathrm{s}, \text { final, }}=0$. Dengan kondisi proyek seperti itu, maka persamaan baseline dalam kegiatan proyek ini menjadi,

$$
\begin{aligned}
& B E_{y}=B E_{w w, t r e a t m e n t, y} \\
& =\Sigma Q_{w w, i, y} \times C_{\text {removed }, i, y} x \\
& M C F_{w w, \text { treatment,BL,i}} \times B_{o, w w} \times \cup F_{B L} \times \\
& \text { GWP }
\end{aligned}
$$

\begin{tabular}{|c|c|c|}
\hline $\mathbf{Q}_{w w, i, y}$ & : & Jumlah limbah air $\left(\mathrm{t} / \mathrm{m}^{3}\right)$ \\
\hline COD ${ }_{\text {removed,i,y }}$ & : & $\begin{array}{l}\text { Nilai COD yang } \\
\text { terambil/terolah. }\end{array}$ \\
\hline $\mathrm{MCF}_{\text {ww,treatment,BL,i }}$ & $:$ & $\begin{array}{l}\text { Koreksi factor gas } \\
\text { metana untuk baseline } \\
\text { pengolahan limbah air, } \\
0.8 \text { (kolam an aerobik } \\
\text { dalam) }\end{array}$ \\
\hline$B_{o, w w}$ & & $\begin{array}{l}\text { Kapasitas produksi gas } \\
\text { metana pada limbah air, } \\
0.21 \mathrm{~kg}\left(\mathrm{CH}_{4} / \mathrm{kgCOD}\right)\end{array}$ \\
\hline $\mathrm{UF}_{\mathrm{BL}}$ & & $\begin{array}{l}\text { Faktor koreksi model } \\
\text { untuk perhitungan } \\
\text { ketidakpastidak mode, } \\
0.94\end{array}$ \\
\hline $\mathrm{GWP}_{\mathrm{CH} 4}$ & $:$ & $\begin{array}{l}\text { Potensi emisi gas } \\
\text { metntana pada sistem } \\
\text { pengolahan limbah air } \\
\text { yang dilengkapi sostem } \\
\text { penangkap gas bio, } 21\end{array}$ \\
\hline
\end{tabular}

dimana,

\section{2) Emisi Proyek}

Emisi proyek yang dihasilkan dari kegiatan proyek ini dihitung berdasarkan metodologi pada AMS-III.H ${ }^{17)}$, dengan persamaan sebagai berikut : 


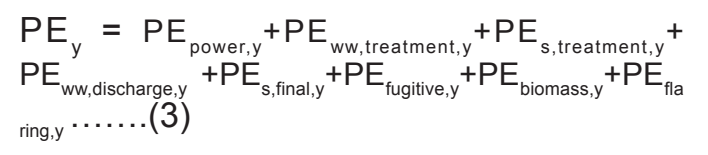

dimana,

\begin{tabular}{|l|l|l|}
\hline $\mathrm{PE}_{\mathrm{y}}$ & $: \begin{array}{l}\text { emisi proyek pada tahun } \\
\mathrm{y}\left(\mathrm{t}-\mathrm{CO}_{2} \text { ) }\right.\end{array}$ \\
\hline $\mathrm{PE}_{\text {power,y }}$ & $: \begin{array}{l}\text { emisi proyek dari listrik } \\
\text { atau kebutuhan bahan } \\
\text { bakar pada tahun y } \\
\left(\mathrm{t}-\mathrm{CO}_{2} \text { ) }\right.\end{array}$ \\
\hline $\mathrm{PE}_{\text {ww,treatment,y }}$ & $: \begin{array}{l}\text { emisi gas metana dari } \\
\text { sistem pengolahan } \\
\text { limbah air yang } \\
\text { diakibatkan kegiatan } \\
\text { proyek dan tidak } \\
\text { dipasang penangkap } \\
\text { gas, pada tahun y (t-CO }\end{array}$ \\
\hline $\mathrm{PE}_{\mathrm{s}, \text { treatment,y }}$
\end{tabular}

$P E_{\text {powery }}$ terdiri dari emisi proyek yang berasal dari kebutuhan listrik dan konsumsi bahan bakar fosil, seperti ditunjukkan dalam AMS.III.H versi 13. Untuk emisi GRK dari konsumsi listrik ditentukan dalam AMS.I.D versi 15, dan emisi GRK dari konsumsi bahan bakar fosil ditentukan dengan emisi factor dari bahan bakar fosil.

Pada proyek ini akan dikonsusmi listrik dan konsumsi bahan bakar fosil. Emisi GRK dari kedua konsumsi tersebut dihitung seperti di bawah ini.

$P E_{\text {power }, y}=P E_{\text {electricity,PJ }, y}+P E_{\text {fossiffuel,PJ,y }} \ldots \ldots$

dimana:

\begin{tabular}{|l|l|}
\hline$P E_{\text {electricity,PJ,y }}$ & $\begin{array}{l}\text { Emisi } \mathrm{CO}_{2} \text { dari konsumsi } \\
\text { listrik dari aktivitas proyek } \\
\text { pada tahun y }\left(\mathrm{tCO}_{2} \mathrm{e} / \text { thn) }\right.\end{array}$ \\
\hline$P E_{\text {fossifuel,PJ,y }}$ & $\begin{array}{l}\text { Emisi } \mathrm{CO}_{2} \text { dari konsumsi } \\
\text { bahan bakar dari aktivitas } \\
\text { proyek tahun y }\left(\mathrm{t} \mathrm{tO}_{2} \mathrm{e} / \mathrm{thn}\right)\end{array}$ \\
\hline
\end{tabular}

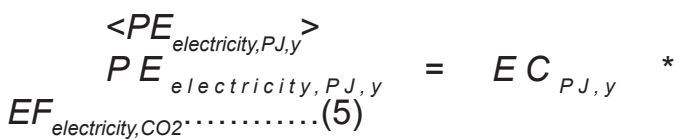
dimana:

\begin{tabular}{|l|l|}
\hline$E C_{P J, y}$ & $\begin{array}{l}\text { Jumlah konsumsi listrik } \\
\text { pada aktivitas proyek tahun } \\
\mathrm{y}(\mathrm{kWh} / \mathrm{thn})\end{array}$ \\
\hline$E F_{\text {electricity, } \mathrm{CO} 2}$ & $\begin{array}{l}\text { Emisi factor } \mathrm{CO}_{2} \text { pada } \\
\left.\text { proyek ( } \mathrm{tCO}_{2} \mathrm{e} / \mathrm{kWh}\right)\end{array}$ \\
\hline
\end{tabular}

Pada proyek ini tidak terkoneksi dengan jaringan listrik PLN dan listrik yang dihasilkan berasal dari pembangkit bahan bakar biomasa dan mesin diesel. saat pembangkit biomasa tidak beroperasi. Kedua jens pembangkit tersebut milik PKS.

Emisi Faktor $\mathrm{CO}_{2}$ berdasarkan AMS. III.H versi 13 dan AMS.I.D versi adalah sebagai berikut :

$$
E F \text { electricity, c o } 2
$$




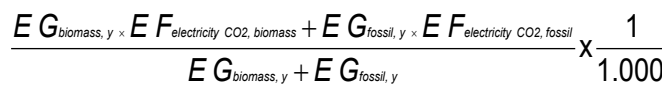

(6)

Dimana:

\begin{tabular}{|c|c|}
\hline$E F_{\text {electricity, } \mathrm{CO} 2}$ & $\begin{array}{l}\text { Emisi Faktor } \mathrm{CO}_{2} \text { di lokasi } \\
\text { proyek }\left(\mathrm{tCO}_{2} \mathrm{e} / \mathrm{kWh}\right)\end{array}$ \\
\hline$E G_{\text {biomass }, y}$ & $\begin{array}{l}\text { Jumlah listrik yang } \\
\text { dibangitkan oleh } \\
\text { pembangkit biomasa } \\
\text { pada tahun y (kWh/thn) }\end{array}$ \\
\hline$E F_{\text {electricity, } \mathrm{CO} \text {, biomass }}$ & $\begin{array}{l}\text { Emisi Faktor } \mathrm{CO}_{2} \text { dari } \\
\text { pembangkit biomasa } \\
\text { pada tahun y }\left(\mathrm{kgCO}_{2} \mathrm{e} /\right. \\
\mathrm{kWh} \text { ). Menurut } \mathrm{AMS}^{\mathrm{III}} \mathrm{H} \\
\text { ver } 13 \text { nilainya adalah } 0 .\end{array}$ \\
\hline$E G_{\text {fossil,y }}$ & $\begin{array}{l}\text { Jumlah listrik yang } \\
\text { dibangkitkan oleh } \\
\text { pembangkit bahan bakar } \\
\text { fosil pada tahun y (kWh/ } \\
\text { thn) }\end{array}$ \\
\hline$E F_{\text {electricity, CO2,fossil }}$ & $\begin{array}{l}\text { Emisi Faktor } \mathrm{CO}_{2} \text { dari } \\
\text { pembangkit biomasa } \\
\text { pada tahun y }\left(\mathrm{kgCO}_{2} \mathrm{e} /\right. \\
\mathrm{kWh}) \text {. Berdasarkan AMS } \\
\mathrm{I} . \mathrm{D} \text { ver } 15 \text {, nilainya adalah } \\
0,8 \text { jika kapasitas }>200 \\
\text { kW. }\end{array}$ \\
\hline
\end{tabular}

Pada proyek ini $\mathrm{EF}_{\mathrm{CO} 2}$ sangat kecil karena listrik yang dikonsumsi sebagain besar dibangkitkan oleh pembangkit bahan bakar biomasa. Jumlah listrik pada tahun 2008 adalah sebagai berikut, 4.278.013 kWh/thn dibangkitkan oleh pembangkit bahan bakar biomasa dan $10.550 \mathrm{kWh} /$ thn oleh pembangkit bahan bakar fosil (diesel). Sehingga EF dapat dihitung sebagai berikut :

$$
\begin{aligned}
E F_{\text {electricity, } \mathrm{CO} 2} & =\frac{4,278,013^{*} 0+10,550^{*} 0.8}{(4,278,013+10,550)^{*} 1,000} \\
& =\frac{8,440}{4,288,563^{*} 1,000} \\
& =0.000002\left(\mathrm{tCO}_{2} / \mathrm{MWh}\right)
\end{aligned}
$$

Total jumlah listrik yang dibutuhkan dalam pada proyek ini, $E C_{P J, y}$ adalah $68 \mathrm{MWh} /$ thn, dengan rincian sebagai berikut :

a. Pompa penyalur

$1,5 \mathrm{~kW} /$ unit $\times 2$ unit/kolam $\times 2$ kolam

$$
=6,0 \mathrm{~kW}
$$

b. Pompa pengaduk

$0,4 \mathrm{~kW} /$ unit $\times 2$ unit/kolam $\times 2$ kolam

$$
=1,6 \mathrm{~kW}
$$

c. Cerobong untuk flaring system

$$
0.2 \mathrm{~kW} \times 1 \mathrm{unit} / \mathrm{site}=0.2 \mathrm{~kW}
$$

Total konsumsi listrik adalah $(6.0+1.6+0.2) \mathrm{kW} \times 24$ hours $\times 365$ days $=$ $68,328 \mathrm{kWh} /$ thn. Emisi $\mathrm{CO}_{2}$ dari konsumsi listrik pada proyek $P E_{\text {electricity,PJ,y }}$ adalah sangat kecil, yaitu ;

$$
\begin{aligned}
& P E_{\text {electricity,PJ,y }}=E C_{P J, y} \times E F_{\text {electricity, }, \mathrm{CO} 2} \\
& =68,328 \times 0.002=0.13\left(\mathrm{tCO}_{2} \mathrm{e} / \mathrm{thn}\right)
\end{aligned}
$$

Karena jumlah emisi $\mathrm{CO}_{2}$ pada konsumsi listrik di proyek ini sangat kecil dibanding total emisi $\mathrm{CO}_{2}$ yang dikeluarkan oleh proyek, maka dapat diabaikan $\left(P E_{\text {power,y }}=0\right)$.

$P E_{\text {fossiffue, } P J, y,}$ adalalah emisi GRK yang berasal dari pembakaran ELPIJI untuk mendukkung pembakaran gas pada system flaring. Perhitungannya ditunjukkan pada persamaan di bawah ini.

$$
\begin{aligned}
& P E_{\text {fossilfuel,PJ,y }}=F C_{L P G, y} \times V_{L P G}^{\mathbf{E}_{L P G, \text { combust }}} x \\
& \frac{\mathrm{E}_{L P G, \text { combust }}}{1.000 .000}
\end{aligned}
$$

dimana

\begin{tabular}{|l|l|}
\hline$P E_{\text {fossiftuel,PJ,y }}$ & $\begin{array}{l}\text { Emisi } \mathrm{CO}_{2} \text { emission dari } \\
\text { konsumsi bahan bakar fosil } \\
\text { pada tahun y (tCO }\end{array}$ \\
\hline$F C_{L P G, y}$ & $\begin{array}{l}\text { Konsumsi ELPIJn) } \\
\text { y (tLPG/thn) }\end{array}$ \\
\hline$E F_{L P G, \text { combust }}$ & $\begin{array}{l}\text { Emisi factor } \mathrm{CO}_{2} \text { dari } \\
\text { pembakaran gas ELPIJI } \\
\text { (kgCO } / \mathrm{TJ})\end{array}$ \\
\hline$H V_{L P G}$ & Nilai kalor gas ELPIJI \\
\hline
\end{tabular}


Proses pengolahan limbah cair secara an aerobik pada aktivitas proyek ini adalah sama dengan kondisi sebelum proyek (baseline), sehingga kualitas air yang diolah/ nilai COD (Chemical Oxygen Demand) limbah air setelah melewati kolam an aerobik pada saat sebelum proyek dan sebelum proyek adalah sama, maka dalam perhitungan ini dapat dianggap $P E_{w w, \text { discharge, } y}=0$.

Lumpur/sludge dari kolam an aerobik diambil secara periodik untuk menjaga kulitas proses pengolahan air dan mencegah pendangkalan kolam. Lumpur diambil dari kolam, dikeringkan dengan sinar matahari dan kemudian dibuang ke lahan perkebunan terdekat sebagai pupuk, sehingga $\mathrm{PE}_{\text {s.final, } y}=0$. Dengan tidak adanya pengolahan lumpur maka pada emisi pada kegiatan tersebut tidak ada, dan tidak ada nilai $\mathrm{PE}_{\mathrm{s}}$ Karena tidak ada biomasa yang disimpan dibawah kondisi an-aerobik, maka tidak ada nilai $\mathrm{PE}_{\text {biomass,y. }}$

Dengan kondisi aktivitas proyek seperti di atas maka persamaan (4) menjadi,

$$
\begin{aligned}
& P E_{y}=P E_{w w, t r e a t m e n t, y}+P E_{\text {fugitive } y}+P E_{\text {flaring }, y}
\end{aligned}
$$

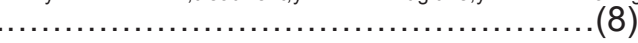

$$
\begin{aligned}
& P E_{\text {fugitive }, y}=P E_{\text {fugitive }, w w, y}+P E_{\text {fugitive }, \mathrm{s}, y}
\end{aligned}
$$

karena pada proyek ini tidak ada sistem pengolahan sludge, maka, nilai $\mathrm{PE}_{\text {fugitive,s,y }}$ tidak ada, sehingga,

$$
\begin{aligned}
& \mathrm{PE}_{\text {fugitive }, y}=\mathrm{PE}_{\text {fugitive }, w w, y} \ldots \ldots \ldots \ldots \ldots \ldots(10) \\
& \mathrm{PE}_{\text {fugitive } w w, y}=\left(1-\mathrm{CFE}_{\mathrm{ww}}\right) \times \mathrm{MEP}_{\text {ww,treatment,y }} \times \mathrm{GWP}_{\mathrm{CH} 4}
\end{aligned}
$$

dimana,

\begin{tabular}{|l|l|}
\hline $\mathrm{CFE}_{w w}$ & $: \begin{array}{l}\text { Efisiensi pengkapan dari } \\
\text { fasilitas penangkapan gas } \\
\text { pada sitem pengolahan limbah, } \\
0.9\end{array}$ \\
\hline $\mathrm{GWP}_{\mathrm{CH} 4}$ & $: \begin{array}{l}\text { Potensi emisi gas metntana } \\
\text { pada sistem pengolahan } \\
\text { limbah air yang dilengkapi } \\
\text { sistem penangkap gas bio, 21 }\end{array}$ \\
\hline
\end{tabular}

Potensi gas metana yang dihasilkan dari limbah cair dari kolam an aerobik dinyatakan dalam persamaan di bawah ini,

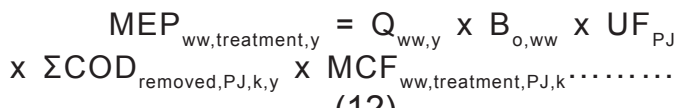

dimana,

\begin{tabular}{|l|l|l|}
\hline $\mathbf{Q}_{\mathrm{ww}, \mathrm{y}}$ & $:$ & Jumlah limbah air $\left(\mathrm{t} / \mathrm{m}^{3}\right)$ \\
\hline $\mathbf{B}_{\mathrm{o}, \mathrm{ww}}$ & $:$ & $\begin{array}{l}\text { Kapasitas produksi gas } \\
\text { metana pada limbah air, } \\
0.21 \mathrm{~kg}\left(\mathrm{CH}_{4} / \mathrm{kgCOD}\right)\end{array}$ \\
\hline $\mathbf{U F}_{\mathrm{PJ}}$ & $:$ & $\begin{array}{l}\text { Faktor koreksi model } \\
\text { untuk perhitungan } \\
\text { ketidakpastidak model, } \\
1.06\end{array}$ \\
\hline $\mathbf{C O D}_{\text {removed,PJ,k,y }}$ & $\begin{array}{l}\text { Jumlah COD yang terambil/ } \\
\text { terolah. }\end{array}$ \\
\hline $\mathbf{M C F}_{\text {ww,treatment,PJ,k }}$ & $\begin{array}{l}0.8(\text { kolam anaerobic } \\
\text { dalam) }\end{array}$ \\
\hline
\end{tabular}

$\mathrm{PE}_{\text {flaring,y }}=\Sigma \mathrm{TM}_{\mathrm{RG}, \mathrm{h}} \times(1-0.9) \times \mathrm{GWP}_{\mathrm{CH} 4}$ 11000

dimana jumlah massa gas metana yang mengalir pada aliran gas bio pada fasilitas pembakaran/flaring dianggap sama dengan jumlah massa gas metana yang dihasilkan kolam an aerobik setelah dikurangi jumlah gas metana yang terlepas pada dari sistem penangkapan gas,

$\sum \mathrm{TM}_{\mathrm{RG}, \mathrm{h}} \times \mathrm{GWP}_{\mathrm{CH} 4} / 1000 \fallingdotseq\left(\mathrm{MEP}_{\text {ww,treatment,y }}\right.$

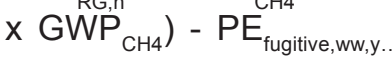

\begin{tabular}{|l|l|l|}
\hline $\boldsymbol{\Sigma} \mathbf{T M}_{\mathrm{RG}, \mathrm{h}}$ & $:$ & $\begin{array}{l}\text { Jumlah massa gas metana } \\
\text { pada aliran gas bio buang } \\
(\mathrm{kg} / \mathrm{h})\end{array}$ \\
\hline
\end{tabular}

Sehingga persamaan (13) dapat dirubah menjadi persamaan di bawah ini,

$$
P E_{\text {flaring,y }}=\left(M_{\text {ww,treatment,y }} \times \mathrm{GWP}_{\mathrm{CH} 4}\right) \mathrm{E}_{\text {fugiti }}
$$




\section{3) Kebocoran/Leakage}

Pada proyek ini, instalasi sistem penangkapan dan pembakaran gas metana merupakan sistem/peralatan yang baru sehingga, kebocoran/leakage dianggap nol, $\mathrm{LE}=0$.

\section{4) Pengurangan Emisi (Emission Reduction)}

Pengurangan emisi dari skenario proyek ini adalah sebagai berikut

$E R_{y, \text { ex ante }}=B E_{y, \text { ex ante }}+B E_{y^{\prime} \text { electricity }}-\left(P E_{y, \text { ex ante }}+\right.$

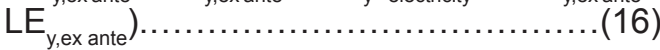
menjadi,

persamaan (16) dapat dirubah $E R_{y, \text { ex ante }}=B E_{w w, \text { treatment, } y}+B E_{y}$, electricity $\left(P E_{\text {ww,treatment,y }}+P E_{\text {fugitive,y }}+P E_{\text {flaring, } y}\right) \ldots \ldots \ldots \ldots . .(17)$

\subsection{Keekonomian Proyek}

Diasumikan untuk proyek CDM diskenariokan bekerjasama dengan pihak pembeli, dimana biaya pengurusan administrasi ditanggung oleh pihak pembeli. Pemilik dari lahan dan limbah cair, PKS Sei Silau tidak mengeluarkan biaya untuk investasi, berkewajiban hanya menyediakan limbah dan lahan untuk proyek ini saja. Harga CER (Credit Emission Reduction) diasumsikan 12.13EURO/ $\mathrm{t}-\mathrm{CO}_{2}{ }^{(18)}$ atau $27,52 \mathrm{USD} / \mathrm{t}-\mathrm{CO}_{2}$.

Nilai investasi untuk flaring gas system berikut covering sheet untuk dua kolam anaerobic seluas masing masing $67.5 \mathrm{x}$ $40 \mathrm{~m} 2$, dan biaya operasional meliputi maintenance alat, gaji pegawai dan biaya verifikasi tiap tahun diasumsikan di table 2 .

\section{HASIL DAN PEMBAHASAN}

\subsection{Pengukuran Air Limbah}

Pada PKS Sei Silau, total jumlah TBS olah pada tahun 2008 adalah 270.235 ton,
Tabel 2 Parameter Keekonomian

\begin{tabular}{|l|l|}
\hline INVESTASI & BIAYA \\
\hline $\begin{array}{l}\text { flaring system+ methane gas } \\
\text { capture+ CDM procedure }\end{array}$ & 836.000 USD \\
\hline O\&M & BIAYA \\
\hline Flaring system & 59.000 USD \\
\hline Verifikasi (proyek CDM) & 30.000 USD \\
\hline
\end{tabular}

dengan rasio air limbah per ton TBS adalah $54,8 \%{ }^{16)}$, maka jumlah air limbah pada tahun itu adalah 145.927 ton. Air sirkulasi dihitung dari kapasitas pompa dalam setahun adalah 356.882 ton. Sehingga total debit air limbah yang masuk ke dalam kolam adalah 502.809 ton.

\subsection{Hasil Pengukuran COD}

Hasil pengukuran COD dan $\mathrm{pH}$ selama 10 hari berturut-turut, dengan lokasi pengukuran pada tanda bulat di kedua inlet pada kolam an-aerobik 1 dan 2 (gambar 8), ditunjukkan pada tabel 3 dan 4 . Air limbah pada PKS Sei Silau ini dialirkan ke kolam anaerobik secara pararel.

Dari hasil pengukuran COD seperti yang ditunjukkan dalam tabel 1 dan 2, COD yang menuju ke kolam anaerobik 1 lebih tinggi dibandingkan yang menuju ke kolam anaerobik 2.

Dari nilai rata-rata data COD selama 10 hari, di kedua inlet kolam anerobik 1 dan 2 diambil rata-ratanya dengan hitungan sebagai berikut. .

$$
\begin{aligned}
& =\frac{27.576,1+13,590,4}{2}+\frac{8,566,9+2,771,5}{2} \\
& =20.583 .3-5.669,2=14.914,1 \mathrm{mg} / \mathrm{tr} \\
& =0,01491 \mathrm{ton} / \mathrm{m}^{3}
\end{aligned}
$$

Rentang reduksi COD di kolam anaerobik 1 dan 2, selama 10 hari berturutturut berkisar antara $46,1 \%-85,3 \%$, dan rata-rata reduksi COD pada kolam 1 dan 2 , masing-masing adalah $68,9 \%$ dan $79,6 \%$.

Total reduksi rata-rata untuk kedua 
kolam anaerobik tersebut adalah $72,5 \%$. Reduksi ini masih relatif rendah dibandingkan hasil pengukuran yang dilakukan Hayashi, dimana kolam anaerobik dapat mengurangi COD sebesar $97.8 \%{ }^{16)}$.

Tabel 3 Data COD dan pH dari kolam 1

\begin{tabular}{|c|l|l|l|l|}
\hline hari & COD inlet & $\mathrm{pH}$ inlet & COD outlet & $\mathrm{pH}$ outlet \\
\hline 1 & $30,078.7$ & 5.20 & $7,963.2$ & 6.67 \\
\hline 2 & $28,788.5$ & 5.31 & $8,265.6$ & 7.29 \\
\hline 3 & $30,401.3$ & 5.78 & $7,096.3$ & 6.63 \\
\hline 4 & $29,111.0$ & 5.58 & $7,660.8$ & 7.27 \\
\hline 5 & $29,917.4$ & 5.69 & $8,426.9$ & 7.50 \\
\hline 6 & $23,887.7$ & 5.22 & $10,420.8$ & 7.96 \\
\hline 7 & $25,971.8$ & 5.33 & $8,697.4$ & 7.90 \\
\hline 8 & $26,282.9$ & 4.89 & $7,659.4$ & 7.14 \\
\hline 9 & $20,139.8$ & 5.23 & $10,847.5$ & 7.17 \\
\hline 10 & $31,181.8$ & 5.21 & $8,631.4$ & 7.18 \\
\hline
\end{tabular}

Tabel 4 Data COD dan pH dari kolam 2

\begin{tabular}{|c|l|l|l|l|}
\hline hari & COD inlet & pH inlet & COD outlet & pH outlet \\
\hline 1 & $19,595.5$ & 5.66 & $2,882.9$ & 7.07 \\
\hline 2 & $13,950.7$ & 5.61 & $2,741.8$ & 7.20 \\
\hline 3 & $10,765.4$ & 5.78 & $2,943.4$ & 7.81 \\
\hline 4 & $17,982.7$ & 5.91 & $2,802.2$ & 7.71 \\
\hline 5 & $14,878.1$ & 5.93 & $2,741.8$ & 7.83 \\
\hline 6 & $7,855.7$ & 6.72 & $2,785.6$ & 7.27 \\
\hline 7 & $8,497.0$ & 6.87 & $2,885.8$ & 7.44 \\
\hline 8 & $18,973.4$ & 6.22 & $2,954.9$ & 7.05 \\
\hline 9 & $7,309.4$ & 6.14 & $2,546.6$ & 6.94 \\
\hline 10 & $16,096.3$ & 6.32 & $2,430.0$ & 6.96 \\
\hline
\end{tabular}

Rendahnya rasio reduksi COD dari inlet dan outlet kolam anaerobik, kemungkinan terjadi dikarenakan kolam anaerobik di PKS Sei Silau relatif dangkal. Secara disain kedalaman kolam adalah $5 \mathrm{~m}$, tetapi pada kenyataannya menumpuknya sludge di kolam tidak secara periodik dikeluarkan dari kolam, maka kedalaman menjadi lebih dangkal. Berdarkan laporan staf lapangan PKS Sei Silau, kedalaman kolam tidak lebih dari $2 \mathrm{~m}$. Pendangkalan ini menyebabkan terjadinya waktu tinggal air limbah menjadi lebih pendek, sehingga mengurangi waktu dekomposisi zat organik.

Nilai COD di saluran input kolam anaerobik, nilainya relatif rendah dibandingkan dengan beberapa referensi yang ada. Pengukuran COD untuk proyek CDM di PKS Perlabian, Sumatera Utara menunjukkan angka 0.076950 ton $/ \mathrm{m}^{319}$ ), dan 0,055410 ton $/ \mathrm{m}^{3}$ dan $0,07256 \mathrm{ton} / \mathrm{m}^{3}$ pada proyek CDM yang lain di PKS Ulu Kanchong, Malaysia ${ }^{20)}$, dan Sabah ${ }^{15)}$.

Dari suatu penelitian terkait nilai COD dari 30 PKS di Indonesia dan 40 PKS di Malaysia, ditunjukkan bahwa rata rata COD di Indonesia berkisar dari 15.300$65.100 \mathrm{mg} / \mathrm{l}$, dengan rata rata $34.720 \mathrm{mg} / \mathrm{l}$, sebagai perbandingan di Malaysia berkisar antara 15.500-106.360 mg/l, dengan ratarata $53.630 \mathrm{mg} / \mathrm{l}$. Target pengukuran COD ini hanya dikhususkan pada PKS yang menggunakan Centrigue Waste, dimana kondisi ini sama dengan kondisi PKS Sei Silau yang tidak memiliki sistem pemisahan antara limbah padat dan cair. ${ }^{1)}$. Dari data tersebut di atas, nilai COD di PKS Indonesia, rata -rata lebih rendah $35,2 \%$ dibandingkan Malaysia

Dari hasil pengukuran di studi ini, nilai COD rata rata dari kedua anaerobik pond adalah $20.582 \mathrm{mg} / \mathrm{l}$, dengan rasio reduksi COD rata-rata adalah $72,5 \%$.

Rendahnya nilai COD pada pengukuran di studi ini, didukung dengan nilai $\mathrm{pH}$ pada inlet kolam anaerobik yang berada di bawah $\mathrm{pH}=7$. $\mathrm{pH}$ pada inlet di kolam anaerobik 1 dan 2 rata-rata adalah 5,34 dan 6,12 . Dimana dalam kondisi $\mathrm{pH}$ ini proses bakteria metnogenik tidak optimum. Bakteri metanogenik akan menghasilkan gas metana secara aktif pada $\mathrm{pH}$ antara 7 dan $\left.8^{21}, 9,11\right)$, sedangkan $\mathrm{pH}$ optimum berkisar pada $6,4-7,4^{10)}$.

Outlet dari kedua kolam anaerobik untuk kolam 1 dan 2 adalah 7,27 dan 7,33. Kondisi $\mathrm{pH}$ pada outlet menyatakan bahwa proses pembentukan gas metana terjadi. Tetapi dengan kondisi inlet $\mathrm{pH}$ yang 
tidak berada dalam $\mathrm{pH}$ optimum bakteri metanogensis untuk menghasilkan gas metana, maka proses yang terjadi di kolam anaerobik disimpulkan tidak dapat terjadi secara optimum.

Rendahnya nilai COD ini dapat terjadi karena adanya volume air yang masuk ke dalam air limbah secara berlebihan. Dari pengamatan di lapangan, air cucian minyak di sekitar Screw Press dan Clarifier Oil Tank, dibuang ke dalam parit yang bersatu dengan air limbah. Pencucian di sekitar kedua alat tersebut diperlukan karena adanya kebocoran minyak. Kebocoran minyak ini perlu dibersihkan untuk menjaga keamanan dan kebersihan lingkungan kerja pabrik. Kondisi kebocoran ini tidak terjadi di PKS di Malaysia, sehingga kondisi ini merupakan jawaban dari penyebab rendahnya COD di PKS di Indonesia dibandingkan di Malaysia.

\subsection{Pemanfaatan Gas Metana}

Dari hasil data 3.1 dan 3.2, potensi sumber gas metana dihitung dengan menggunakan persamaan di 2.4. Jumlah gas metana yang dihasilkan dari dua kolam anaerobik tiap tahun adalah $1.054 \mathrm{t}-\mathrm{CH}_{4} /$ tahun atau $22.133 \mathrm{t}-\mathrm{CO}_{2} /$ tahun

\subsection{Pengurangan Emisi GRK}

Jika proyek ini dimasukkan ke dalam proyek CDM, dengan skenario flaring, atau pembakaran gas metana saja. Maka proyek ini mempunyai arti sebagai proyek yang berkontribusi terhadap pengurangan GRK, dengan cara penangkapan dan pembakaran gas metana. Aktifitas dari proyek ini kemudian jika disertifikatkan kepada badan PBB yang mengurusi pengurangan GRK, sebagai sebuah proyek CDM. Maka proyek ini akan mendapatkan pendapatan dari hasil penjualan sertifikat tersebut.

Ketika proyek belum dilaksanakan kolam anaerobik 1 dan 2 mengeluarkan emisi, $\mathrm{BE}_{\mathrm{y}}=\mathrm{BE}_{\mathrm{ww}, \text { treatment, } \mathrm{y}}$, sebesar 22.133
$\mathrm{t}-\mathrm{CO}_{2}$ /tahun.

Dan ketika proyek ini berjalan proyek akan menghasilkan emisi yang merupakan penjumlahan dari,

$$
P E_{y}=P E_{\text {ww,treatment, } y}+P E_{\text {fugitive }, y}+P E_{\text {flaring, } y}
$$
atau $26.15+2.804+2.524=5.354 \mathrm{t}-\mathrm{CO}_{2} /$ tahun.

Dengan begitu proyek ini dapat mereduksi emisi $\mathrm{CO}_{2}$ sebesar $16.779 \mathrm{t}-\mathrm{CO}_{2} /$ thn (=22.133 - 5.354).

\subsection{Proyek CDM}

Sebagai proyek CDM, emisi GRK yang didapat dapat disertifikatkan, dan jika sertifikasi proyek dapat disetujui oleh UNFCCC. Proyek baru bisa mendapatkan pendapatan dari CER setelah dilakukan verifikasi oleh pihak ke tiga 6 bulan atau 12 bulan proyek berjalan.

\subsection{Analisa Keekonomian}

Pendapatan dari proyek ini, hanya berasal dari penjualan CER (Credit Emission reduction), tanpa adanya pendapatan dari CER maka proyek ini tidak layak secara keekonomian, karena tidak adanya pendapatan.

Penjualan CER bergantung kepada besarnya emisi GRK yang dikurangi selama proyek berjalan dalam setahun, selama 7 tahun. Proyek ini dapat mengurangi emisi GRK sebanyak $22.133 \mathrm{t}-\mathrm{CO}_{2}$ /tahun.

Dengan asumsi harga CER adalah 12.13EURO/t- $\mathrm{CO}_{2}$, maka pendapatan yang didapat dari CER per tahun adalah USD 461.758. Dengan memperhitungkan nilai investasi dan biaya operasional seperti ditunjukkan di tabel 4, maka nilai IRR dari proyek ini adalah $28.83 \%$. Bunga pinjaman rata rata bank menurut Bank Indonesia pada awal tahun 2010 adalah sekitar 20\% ${ }^{(22)}$ maka proyek ini dapat dinilai sangat layak. 


\section{KESIMPULAN}

Dari hasil survei ditemukan, bahwa potensi gas metana pada kolam limbah berkaitan erat dengan selisih COD (Chemical Oxygen Demand) yang berkurang di inlet dan outlet kolam anaerobik.

Nilai COD pada PKS Sei Silau relatif rendah dibandingkan dengan nilai COD dari PKS di negara lain. Rendahnya nilai COD ini dikarenakan adanya pencampuran air buangan yang berasal dari proses pencucian dan proses lain di dalam pabrik ke dalam saluran pembuangan air limbah., yang mengakibatkan pencairan air limbah.

Sebagai proyek CDM, proyek pemanfaatan gas metana dari dua kolam anaerobik di PKS Sei Silau merupakan proyek yang layak secara keekonomian.

\section{UCAPAN TERIMA KASIH}

Ucapan terima kasih ditujukan kepada Manager Pabrik PKS Sei Silau, PTPN 3, Bapak Herbert yang telah membeirkan kesempatan untuk melakukan analisa dan observasi serta pengumpulan data di lapanngan.

\section{DAFTAR PUSTAKA}

1. http://www.palmoilmill-community.com. limbah/25-effluent/56-pen....

2. Keputusan Menteri Negara Lingkungan Hidup, No. 28 tahun 2003, tentang Pedoman Teknis Pengkajian Pemanfaatan Air Limbah dari Industri Minyak Kelapa Sawit pada Tanah di Perkebunan Kelapa Sawit.

3. Rachmawan Budiarto, Potensi Energi Limbah Pabrik Kelapa Sawit, BSS_325_1_1-6, 2007.

4. Ali Akbar, Z.L, Biological Treatment of Palm Oil Mill Effluent (POME) using an Up-Flow Anaerobic Sludge Fixed Film
(UASFF) Bioreactor, thesis for degree of Doctor of Philosophy, 2003.

5. Abdullah, K., Abul Kohar Irwanto, Nirwan Siregar, Endah Agustina, Armansyah H. Tambunan, M. Yasin, Edy Hartulistyono, Y. Aris Purwanto, 1991. Energi dan Listrik Pertanian, JICA-DGHE/IPB Project/ADAET, JTA9a (132).

6. Yadava, L.S. and P.R. Hesse, 1981. The development and Use of Biogas Technology in Rural Area of Asia (A Status Repoert 1981). Improving Soil Fertility through Organic Recycling, FAO/ UNDP Regional Project RAS/75/004, Project Field Document No. 10.

7. Teguh Wikan W, N. Ana dan R. Elita, Pemanfaatan Limbah Industri Pertanian Untuk Energi Biogas",2007

8. Gunnerson, C.G. and D.C. Stuckey, 1986, Anaerobic Digestion: "Principles and Practices for Biogas System. The Worl Bank Washington, D.C., U.S.A.

9. Sosnowski, P., A, Wieczorek, \& S. Ledakowicz, "Anaerbobic co-digestion os sewage sludge and organic fraction of municipal solid wastes, Adv, Environ Res, 2003. 7(3), pp. 609-616.

10. Renita Manurung, Proses Anaerobik sebagai Alternatif untuk Mengolah Limbah Sawit,e-USU Repository, Univeristas Sumatera Utara, 2004.

11. Mahajoeno, Edwi, Lay, Bibiana Widiati, Sutjahjo, Suryo Hadi, dan Siswanto. 2008. Potensi Limbah Cair Pabrik Minyak Kelapa Sawit untuk Produksi Biogas. Jurnal Bioversitas Volume 9 No. 1.

12. D.P Cassidy, P.J. Hirl and E. Belia, 
Methane production from ethanol anaerobics SBRs, Water Science \& Technoloogy-WST, 58-4, 2008, pp. 789-793.

13. http://websisni.bsn.go.id/index.php?/ sni_main/sni/cari_simple

14. http://cdm.unfccc.int/Projects/ projsearch.html.2006

15. Project Design Document of Solids Separation of POME and co-composting project, Sabah,2007

16. K., Hayashi, Environmental Impact of Palm Oil Industry in Indonesia, Proceeding of International Symposium on Eco Topia Science 2007, ISETS07 (2007)

17. "Approved small-scales methodologies", http://cdm.unfccc.int/methodologies/ approved.html,2010

18. Cristian Retamal, Understanding CER price volatility, Carbon Management Consulting Group, Latin Carbon Forum, Panama, June 252009
19. Project Design Document of Methane Recovery in Wastewater Treatment, Project AIN07-W-05, Sumatera Utara, Indonesia, Ver. 1, 14 November 2007.

20. Project Design Document of Methane Recovery in Wastewater Treatment, Biogas Recovery at Ulu Kanchong Palm Oil Mill, 15 January 2009.

21. I.A.Zakaria, H.A. Tajaradin, I.Abustan dan N. Ismail, Relationship between Methane Production and Chimica, Oxygen Demand (COD) in Anaerobic Digestion of Food Waste, International Conference on Construction and Building Technology (ICCBT)-D-(03), pp.28-36

22. Jakarta Post, http://www.thejakartapost. com/news/2010/03/05/central-bankkeeps-key-rate-low-push-bank-lending. html, 19 Maret 2010 